\section{TEMPERATURE DEPENDENCE OF LINCOMYCIN PRODUCTION BY THERMODURIC STREPTOMYCES ESPINOSUS STRAINS}

\section{FRITZ REUSSER}

The Upjohn Company

Kalamazoo, MI 49001, USA

(Received for publication February 4, 1985)

In the course of our antibiotic screening program several lincomycin-producing Streptomyces espinosus strains were isolated. These strains show a remarkable temperature dependence regarding the production of lincomycin. At incubation temperatures up to $28^{\circ} \mathrm{C}$ little or no lincomycin is produced despite good mycelial growth. Incubation above $28^{\circ} \mathrm{C}$ results in an up to hundred-fold increase of antibiotic titers. Hence these organisms possess a drastic and sharp incubation temperature threshold $\left(>28^{\circ} \mathrm{C}\right)$ above which significant antibiotic synthesis is initiated.

The strains used in this study were characterized as $S$. espinosus Dietz sp. n. biotypes UC 5371, 5372, 5408 and 5498 respectively. All fermentations described in Table 1 were conducted under submerged culture conditions in 500-ml Erlenmeyer flasks containing $100 \mathrm{ml}$ of medium. Seed cultures were prepared in a medium containing in $\mathrm{g} /$ liter; glucose monohydrate 25, Pharmamedia (Traders Oil Mill, Fort Worth, Texas) 25. The $\mathrm{pH}$ was adjusted to 7.2 before sterilization. The seed flasks were inoculated from a frozen agar plug and incubated on a rotary shaker $(250 \mathrm{rpm}, 6 \mathrm{~cm}$ stroke) at $28^{\circ} \mathrm{C}$ for 3 days. The fermentation medium contained in $\mathrm{g} /$ liter; black strap molasses 20, dextrin 30, fish meal 15, and Pharmamedia 15. This medium was adjusted to $\mathrm{pH} 7.2$ before sterilization. The fermentation flasks were inoculated with $5 \mathrm{ml}$ of seed culture and incubated on a rotary shaker. Lincomycin was assayed by the standard disc-plate agar diffusion method using Micrococcus luteus UC 130 as the indicator organism. For the temperature shift studies where cell masses were determined a clear medium was needed. Its composition was in g/liter; Tryptone (Difco) 10, yeast extract (Difco) 5, $\mathrm{NaCl}$ 5. All other fermentation conditions were as described above. Cell masses were determined by centrifugation of $10 \mathrm{ml}$ broth aliquots in a clinical centrifuge for 10 minutes. The volume of the wet pellets was then recorded in $\mathrm{ml}$ and corresponds to \% wet mycelial mass.

The temperature dependence of lincomycin production with the four strains was studied at $28^{\circ} \mathrm{C}$ and $45^{\circ} \mathrm{C}$. The results indicate that all strains produced none or trace amounts when incubated at $28^{\circ} \mathrm{C}$ but three strains produced up

Table 1. Lincomycin production by thermoduric S. espinosus strains.

\begin{tabular}{|c|c|c|c|c|c|c|c|c|c|}
\hline Strain & $\begin{array}{c}\text { Incubation } \\
\text { temp } \\
\left({ }^{\circ} \mathrm{C}\right)\end{array}$ & Day & $\mathrm{pH}$ & $\begin{array}{l}\text { Lincomycin } \\
(\mu \mathrm{g} / \mathrm{ml})\end{array}$ & Strain & $\begin{array}{l}\text { Incubation } \\
\text { temp } \\
\left({ }^{\circ} \mathrm{C}\right)\end{array}$ & Day & $\mathrm{pH}$ & $\begin{array}{l}\text { Lincomycin } \\
\quad(\mu \mathrm{g} / \mathrm{ml})\end{array}$ \\
\hline \multirow[t]{8}{*}{ UC 5371} & \multirow[t]{4}{*}{28} & 2 & 6.6 & 0 & \multirow[t]{8}{*}{ UC 5408} & \multirow[t]{4}{*}{28} & 2 & 6.6 & Trace \\
\hline & & 3 & 7.8 & 0 & & & 3 & 8.1 & Trace \\
\hline & & 4 & 8.3 & 0 & & & 4 & 8.4 & Trace \\
\hline & & 5 & 8.5 & Trace & & & 5 & 8.7 & Trace \\
\hline & \multirow[t]{4}{*}{45} & 2 & 8.3 & 920 & & \multirow[t]{4}{*}{45} & 2 & 8.5 & 340 \\
\hline & & 3 & 8.6 & 430 & & & 3 & 8.7 & 360 \\
\hline & & 4 & 8.8 & 350 & & & 4 & 8.7 & 480 \\
\hline & & 5 & 8.7 & 450 & & & 5 & 8.6 & 570 \\
\hline \multirow[t]{8}{*}{ UC 5372} & 28 & 2 & 6.5 & 0 & \multirow[t]{8}{*}{ UC 5498} & \multirow[t]{4}{*}{28} & 2 & 6.8 & 5 \\
\hline & & 3 & 7.5 & 0 & & & 3 & 7.8 & 6 \\
\hline & & 4 & 8.4 & 0 & & & 4 & 8.3 & 7 \\
\hline & & 5 & 8.6 & 0 & & & 5 & 8.5 & 8 \\
\hline & \multirow[t]{4}{*}{45} & 2 & 8.2 & 20 & & \multirow[t]{4}{*}{45} & 2 & 8.2 & 600 \\
\hline & & 3 & 8.5 & 20 & & & 3 & 8.5 & 600 \\
\hline & & 4 & 8.7 & 20 & & & 4 & 8.6 & 730 \\
\hline & & 5 & 8.7 & 20 & & & 5 & 8.7 & 690 \\
\hline
\end{tabular}


Table 2. Effect of temperature shifts on S. espinosus strain UC 5498.

\begin{tabular}{|c|c|c|c|c|c|c|c|c|c|}
\hline $\begin{array}{l}\text { Incubation } \\
\text { temp } \\
\left({ }^{\circ} \mathrm{C}\right)\end{array}$ & Day & $\mathrm{pH}$ & $\begin{array}{c}\text { Mycelial } \\
\text { wet mass } \\
(\%)\end{array}$ & $\begin{array}{l}\text { Lincomycin } \\
(\mu \mathrm{g} / \mathrm{ml})\end{array}$ & $\begin{array}{c}\text { Incubation } \\
\text { temp } \\
\left({ }^{\circ} \mathrm{C}\right)\end{array}$ & Day & $\mathrm{pH}$ & $\begin{array}{c}\text { Mycelial } \\
\text { wet mass } \\
(\%)\end{array}$ & $\begin{array}{l}\text { Lincomycin } \\
\quad(\mu \mathrm{g} / \mathrm{ml})\end{array}$ \\
\hline 25 & 1 & 8.0 & 0.7 & 0 & 37 & 1 & 8.2 & 0.9 & 1 \\
\hline 25 & 2 & 8.4 & 1.0 & 1 & 37 & 2 & 8.5 & 0.9 & 72 \\
\hline 25 & 3 & 8.7 & 1.0 & 5.5 & 37 & 3 & 8.8 & 0.8 & 100 \\
\hline 25 & 4 & 8.8 & 1.0 & 5 & 37 & 4 & 8.8 & 0.9 & 100 \\
\hline 25 & 5 & 8.8 & 1.0 & 5 & 37 & 5 & 8.8 & 1.0 & 100 \\
\hline 25 & 1 & 8.0 & 0.7 & 0 & 37 & 1 & 8.2 & 0.9 & 1 \\
\hline 25 & 2 & 8.4 & 1.0 & 1 & 37 & 2 & 8.5 & 0.9 & 72 \\
\hline 37 & 3 & 8.8 & 1.0 & 17 & 25 & 3 & 8.8 & 0.9 & 80 \\
\hline 37 & 4 & 8.9 & 1.0 & 90 & 25 & 4 & 8.8 & 1.0 & 80 \\
\hline 37 & 5 & 8.8 & 0.9 & 90 & 25 & 5 & 8.8 & 1.0 & 82 \\
\hline
\end{tabular}

to $500 \sim 900 \mu \mathrm{g}$ of lincomycin per $\mathrm{ml}$ when incubated at $45^{\circ} \mathrm{C}$ (Table 1). Peak titers were attained in $2 \sim 3$ days.

Temperature shift experiments were done with S. espinosus strain UC 5498 in a clear medium to assess mycelial mass in addition to other fermentation parameters such as $\mathrm{pH}$ and antibiotic titers. Peak titers in this clear medium were lower than in the regular medium and amounted to $100 \mu \mathrm{g}$ of lincomycin per $\mathrm{ml}$ if the culture was continually incubated at $37^{\circ} \mathrm{C}$ and approximately $5 \mu \mathrm{g} / \mathrm{ml}$ if the culture was incubated at $25^{\circ} \mathrm{C}$ (Table 2). If the culture was incubated at $25^{\circ} \mathrm{C}$ for 2 days followed by a shift to an incubation temperature of $37^{\circ} \mathrm{C}$, the strain commenced to synthesize larger amounts of lincomycin. Peak titers nearly equaled the ones observed in cultures continually kept at $37^{\circ} \mathrm{C}$. Conversely if the strain was incubated first at $37^{\circ} \mathrm{C}$ for 2 days and then shifted to $25^{\circ} \mathrm{C}$ for several additional days, titers peaked about $10 \%$ above the titers present at the time of the temperature shift. In terms of growth as reflected by the mycelial wet mass, the strain grew equally well at $25^{\circ} \mathrm{C}$ or $37^{\circ} \mathrm{C}$.

In a detailed temperature dependence study with strain UC 5498 it was found that only low levels of lincomycin were produced at incubation temperatures up to $28^{\circ} \mathrm{C}$. Incubation above this temperature and covering a range from $>28$ to $45^{\circ} \mathrm{C}$ resulted in a drastic increase of lincomycin production and the peak titers were equal regardless of the specific incubation temperature within this range. The strain grew well at $50^{\circ} \mathrm{C}$ but ceased to produce lincomycin at that incubation temperature.

The temperature-dependent lincomycin production by these strains offers thus a system whereby antibiotic synthesis is inducible or suppressible by simply changing the incubation temperatures of the cultures. 